\title{
Flooding Associated with Typhoon Chata'an, July 5, 2002, Guam
}

By Richard A. Fontaine

\section{INTRODUCTION}

On July 5, 2002, starting at about 8 a.m., the southern half of the eye of Typhoon Chata'an passed directly over the northern part of the island of Guam. Data collected on Guam indicate that the typhoon had sustained winds of 85 to 90 miles per hour ( $\mathrm{mi} / \mathrm{hr}$ ) with gusts of up to $115 \mathrm{mi} / \mathrm{hr}$ (Charles Guard, National Weather Service, written commun., 2003). Storm rainfall totals exceeded 21 inches (in.) over the mountainous areas in south-central Guam. During the peak of the storm, rain fell at rates of up to 6.48 inches per hour (in/hr). Because of the damage caused by Typhoon Chata' an, the President signed a major disaster declaration on July 6 , 2002.

Damages associated with Typhoon Chata'an, while considered moderate relative to other storms that have affected Guam, amounted to several tens of millions of dollars. In excess of 1,000 single-family and multi-family homes were either extensively damaged or destroyed. Electrical power was out for several days over most of the island and no potable water was available through public distribution systems (Federal Emergency Management Agency, 2002). The extreme rainfall led to flooding in southern Guam and caused numerous landslides and severe erosion along water courses. The most significant evidence of these effects could be found in the Fena Valley Reservoir, where elevated sediment concentrations made the water unsuitable for use as a domestic water supply for several days. During normal operation, Fena Valley Reservoir supplies most of the drinking water for the military and some of the general public in southern Guam. All of the stream-gaging stations operated by the U.S. Geological Survey (USGS) on Guam were damaged to some extent during the flood and three of the stations were totally destroyed.

Peak flows in many rivers in southern Guam reached record levels during Typhoon Chata'an. New record peak stages and/or flows of record occurred at 14 of 15 sites where the USGS has collected data. In some areas, the magnitude of flood peaks exceeded previous records significantly. Peak flows had recurrence intervals of 80 years or more at 9 of the 13 sites where sufficient data were available to make the computations. Four of the 9 sites had recurrence intervals that were determined to be greater than 100 years.

In this fact sheet, storm rainfall totals and maximum rainfall totals for durations of 1-, 3-, 6-, and 12-hours are summarized for 12 rain gages on Guam. Peak stages and/or flows were computed at 15 USGS streamflow-gaging stations and recurrence intervals for the peaks determined. Rainfall and streamflowgaging stations operated by the USGS on Guam are supported by funding provided by numerous agencies including the U.S. Navy, the U.S. Army Corps of Engineers (USACE), and the University of Guam through the Water and Environmental Research Institute (WERI). The USGS Office of Surface Water, as part of a national program to document the effects of extreme floods in the United States, provided funding to support the preparation of this fact sheet.

\section{RAINFALL}

Total rainfall for the period of the storm (July 4-5, 2002) and maximum rainfall totals for durations of 1-, 3-, 6-, and 12-hours at 12 rain gages are shown in table 1 . Included in table 1 are data for 7 USGS rain gages, provisional data for 3 National Weather Service (NWS) rain gages (Charles Guard, National Weather Service, written commun., 2003), and provisional data for 2 rain gages operated as part of the Tropical Rainfall Measuring Mission (TRMM) (Mark Lander, University of Guam Water and Environmental Research Institute, written commun., 2003). The locations of the 12 gages and total rainfall for July 4-5, 2002 are shown in figure 1.

Storm rainfall totals for Typhoon Chata' an exhibited a distinctive pattern. The northern part of Guam received less than 10 in. of rain, and rainfall totals gradually increased to values of 10 to $13 \mathrm{in}$. in the central part of the island. Further south there is a sharp gradient in rainfall totals between the central part of the island and the upland areas of south-central Guam, especially in the vicinity of the Fena Valley Reservoir, where rainfall totals of 19 to 21 in. were recorded. Rainfall totals drop off sharply in the extreme southern part of the island. Rainfall totals at Mount Jumullong Manglo, Umatac, and Merizo rain gages were $19.20,14.16$, and 8.3 in., respectively. This rainfall pattern is evident from the data in figure 1 and in table 1 , which lists the gages from north to south.

The pattern of storm total rainfall is a direct response to the path followed by Typhoon Chata'an across Guam. During the passage of a typhoon, the areas within the eye of the storm receive lesser amounts of rainfall and areas just outside the eye in the eye wall of the storm receive the maximum amounts of rainfall. Rainfall totals diminish with increasing distance away from the outer edge of the eye wall (Mark Lander, University of Guam Water and Environmental Research Institute, oral commun., 2003). The southern half of the eye of Typhoon Chata'an passed directly over the northern part of Guam. The distribution of rainfall totals indicates that the southern edge of the eye passed near the central part of the island in the area where dramatic increases in rainfall were recorded.

Maximum rainfall intensities during the storm show the same pattern as total rainfall. Rain gages in north-central Guam recorded maximum 1-hour rainfall totals that ranged from 1.17 in. at Mount Santa Rosa to 2.64 in. at Andersen Air Force Base. The Almagosa rain gage, near the Fena Valley Reservoir, recorded a maximum 1-hour total of 6.48 in. Further to the south intensities diminished with a maximum 1-hour rainfall total of 2.24 in. recorded at Merizo. The distribution of hourly rainfall during the storm at the University of Guam, Almagosa, and Umatac rain gages is shown in figure 1 . Rainfall at the University of Guam gage, which is in an area that was likely within the eye of the storm, lacks the significant spikes of high rainfall intensities recorded at the Almagosa and Umatac gages, which were both in an area to the south of the eye in the eye wall of the typhoon.

Maximum rainfall intensities were recorded between 8 and 10 a.m. (fig. 1). This period corresponds with the time when the eye of the typhoon reached and transversed the northern part of the island. In the areas of the typhoon eye wall, the period of maximum 
Table 1. Maximum rainfall totals, in inches, for selected durations, Typhoon Chata'an, July 4-5, 2002, Guam

[USGS, U.S. Geological Survey; TRMM, Tropical Rainfall Measuring Mission; NWS, National Weather Service; --, not available]

\begin{tabular}{|c|c|c|c|c|c|}
\hline Rainfall gage & 1 hour & 3 hours & 6 hours & 12 hours & July 4-5 \\
\hline $\begin{array}{l}\text { Andersen Air Force Base } \\
\text { TRMM gage }\end{array}$ & 2.64 & 4.14 & 4.82 & 6.40 & $7.12^{\mathrm{b}}$ \\
\hline $\begin{array}{l}\text { Mount Santa Rosa } \\
\quad \text { USGS gage } 133209144545301\end{array}$ & 1.17 & 1.91 & 2.36 & 3.39 & 5.50 \\
\hline $\begin{array}{l}\text { Weather Forecast Office, Guam } \\
\text { NWS gage }\end{array}$ & 2.48 & -- & 5.27 & 8.64 & 10.44 \\
\hline $\begin{array}{l}\text { Sinajana } \\
\quad \text { NWS gage }\end{array}$ & -- & -- & -- & -- & 10.90 \\
\hline $\begin{array}{l}\text { University of Guam } \\
\text { TRMM gage }\end{array}$ & 2.33 & 3.84 & 6.97 & 9.17 & 10.88 \\
\hline $\begin{array}{l}\text { Mount Chachao } \\
\quad \text { USGS gage } 132617144423366\end{array}$ & -- & -- & -- & -- & $12.72^{\mathrm{d}}$ \\
\hline $\begin{array}{l}\text { Windward Hills } \\
\text { USGS gage } 132234144441966\end{array}$ & 3.24 & 6.48 & 8.64 & 10.44 & 13.32 \\
\hline $\begin{array}{l}\text { Fena Reservoir Pump Station } \\
\quad \text { USGS gage } 132132144422366\end{array}$ & 5.64 & 10.56 & 13.92 & 16.08 & 19.08 \\
\hline $\begin{array}{l}\text { Almagosa } \\
\quad \text { USGS gage } 132105144405166\end{array}$ & 6.48 & 12.24 & 15.60 & 17.88 & 21.12 \\
\hline $\begin{array}{l}\text { Mount Jumullong Manglo } \\
\quad \text { USGS gage } 131921144401301\end{array}$ & 5.88 & 10.80 & 13.68 & 15.96 & 19.20 \\
\hline $\begin{array}{l}\text { Umatac } \\
\text { USGS gage } 131729144393766\end{array}$ & 4.20 & 7.44 & 10.08 & 11.76 & 14.16 \\
\hline $\begin{array}{l}\text { Merizo } \\
\quad \text { NWS gage }\end{array}$ & 2.24 & -- & 5.89 & -- & $8.3^{\mathrm{e}}$ \\
\hline
\end{tabular}

${ }^{a}$ Provisional rainfall data from Mark Lander, University of Guam Water and Environmental Research Institute

${ }^{\mathrm{b}}$ Rainfall total through 12:00 a.m. on July 5

${ }^{c}$ Provisional rainfall data from Charles Guard, National Weather Service, Guam

${ }^{\mathrm{d}}$ Estimated storm total based on proration of accumulated total for period July 2-15, 2002

${ }^{\mathrm{e}}$ Estimated storm total based on ratio of maximum 6-hour to storm-total rainfall at the Umatac rain gage

Table 2. Peak flows and stages and associated recurrence intervals for Typhoon Chata'an on July 5, 2002 and previous record peak stages and flows at U.S. Geological Survey streamflow-gaging stations on Guam [ $\mathrm{ft}^{3} / \mathrm{s}$, cubic feet per second; CSG, crest-stage gage; n.a., not applicable; n.d., not determined; <, actual value is less than value shown; >, actual value is greater than value shown]

\begin{tabular}{|c|c|c|c|c|c|c|c|c|}
\hline \multirow[b]{2}{*}{$\begin{array}{l}\text { Station } \\
\text { number }\end{array}$} & \multirow[b]{2}{*}{ Station name } & \multicolumn{2}{|c|}{ Previous record } & \multirow[b]{2}{*}{$\begin{array}{l}\text { Date of } \\
\text { previous peak }\end{array}$} & \multirow[b]{2}{*}{$\begin{array}{l}\text { Period of peak } \\
\text { records }\end{array}$} & \multicolumn{2}{|c|}{ July 5, 2002} & \multirow[b]{2}{*}{$\begin{array}{c}\text { Recurrence } \\
\text { interval } \\
\text { (years) }\end{array}$} \\
\hline & & $\begin{array}{c}\text { Peak flow } \\
\left(\mathrm{ft}^{3} / \mathrm{s}\right)\end{array}$ & $\begin{array}{l}\text { Peak } \\
\text { stage } \\
\text { (feet) }\end{array}$ & & & $\begin{array}{c}\text { Peak flow } \\
\left(\mathrm{ft}^{3} / \mathrm{s}\right)\end{array}$ & $\begin{array}{l}\text { Peak } \\
\text { stage } \\
\text { (feet) }\end{array}$ & \\
\hline 16807200 & Agana River at Agana (CSG) & 600 & n.a. & $09 / 06 / 1985$ & 1985-1989 & 1,720 & n.a. & $<10^{\mathrm{a}}$ \\
\hline 16807600 & Asan River at Asan (CSG) & n.a. & 10.10 & $11 / 03 / 1997$ & $1997-2002$ & 3,920 & 12.27 & $>100^{\mathrm{a}}$ \\
\hline 16807650 & Aplacho River at Apra Heights & 929 & 23.55 & $09 / 07 / 2000$ & $2000-2002$ & 1,690 & 25.22 & $>100^{\mathrm{b}}$ \\
\hline 16808120 & Namo River at Santa Rita (CSG) & 1,220 & n.a. & $09 / 11 / 1989$ & $\begin{array}{c}1985-1989 \\
2002\end{array}$ & 1,810 & 9.60 & $<10^{\mathrm{b}}$ \\
\hline 16809500 & La Sa Fua River near Agat & n.a. & n.a. & n.a. & 2002 & 1,980 & 13.5 & $100^{\mathrm{b}}$ \\
\hline 16809600 & $\begin{array}{l}\text { La Sa Fua River at } 310 \text { feet near } \\
\text { Umatac }\end{array}$ & 1,440 & $6.05^{\mathrm{c}}$ & $09 / 27 / 1978$ & $\begin{array}{l}1954-1960 \\
1977-1983 \\
2000-2002\end{array}$ & 2,140 & 17.73 & 50 \\
\hline 16816000 & Umatac River at Umatac & 7,460 & 7.04 & $10 / 19 / 1960$ & $\begin{array}{c}1954-1976 \\
2002\end{array}$ & $6,240^{\mathrm{d}}$ & $10.75^{\mathrm{d}}$ & 15 \\
\hline 16846000 & Tolaeyuus River at mouth & n.a. & 20.47 & $12 / 17 / 1997$ & $\begin{array}{l}1994-1995 \\
1997-2002\end{array}$ & n.d. & 28.06 & n.d. \\
\hline 16847000 & Imong River near Agat & 6,100 & 11.30 & $09 / 27 / 1978$ & $1961-2002$ & $5,920^{\mathrm{d}}$ & $13.53^{\mathrm{d}}$ & 80 \\
\hline 16848100 & Almagosa River near Agat & 2,650 & 7.78 & $09 / 27 / 1978$ & $1972-2002$ & 6,330 & 10.80 & 90 \\
\hline 16848500 & Maulap River near Agat & 2,420 & 9.20 & $09 / 27 / 1978$ & $1972-2002$ & 5,340 & 11.23 & $>100$ \\
\hline 16849000 & Fena Dam Spillway near Agat & n.a. & 4.50 & $10 / 15 / 1953$ & $1953-2002$ & n.a. & 5.36 & $>100^{\mathrm{e}}$ \\
\hline 16854500 & Ugum River above Talofofo Falls & 5,890 & 14.2 & $02 / 26 / 1980$ & $1977-2002$ & 14,700 & 21.50 & 80 \\
\hline 16858000 & Ylig River near Yona & 3,410 & 18.63 & $12 / 16 / 1997$ & $1953-1998$ & n.d. & 23.45 & n.d. \\
\hline 16865000 & Pago River near Ordot & 10,100 & 20.15 & $05 / 21 / 1976$ & $\begin{array}{l}1952-1982 \\
1999-2002\end{array}$ & 16,500 & 23.55 & 90 \\
\hline
\end{tabular}

a Recurrence interval based on peak discharge data published in the Flood Insurance Study, Territory of Guam (Federal Emergency Management Agency, 1998)

${ }^{b}$ Recurrence interval based on regional, peak discharge, regression equations published in the Flood Insurance Study, Territory of Guam (Federal Emergency Management Agency, 1998)

${ }^{\mathrm{c}}$ Gage datum was changed by 10.00 feet in 2000 ; the previous peak stage of record would be 16.05 feet using the current gage datum

${ }^{\mathrm{d}}$ During Typhoon Chata' an a new record peak stage was established but not a new record peak flow. This was the result of changes in the stage-discharge ratings between the time of the previous record peaks and Typhoon Chata'an

${ }^{\mathrm{e}}$ Recurrence interval based on analysis of peak stages 
rainfall intensities likely corresponded to times when wind speed was high. It is well documented that rain gages under-register rainfall in windy conditions and that the magnitude of this error increases with wind speed; Larson and Peck (1974) reported rainfall catch deficiencies of about 20 percent at winds speeds of $20 \mathrm{mi} / \mathrm{hr}$. Wind speeds during the passage of the typhoon and the periods of maximum recorded rainfall intensities were likely to have been significantly greater than $20 \mathrm{mi} / \mathrm{hr}$. Actual maximum rainfall intensities were therefore likely to have been much greater than the intensities recorded.

\section{PEAK FLOWS}

As part of this study, peak flows and/or peak stages were determined at 15 current or former USGS stream gages in Guam. The peak flow and stage data are summarized in table 2 and the locations of the gages are shown in figure 1. Northern Guam has essentially no stream drainage because the area is composed primarily of permeable limestone through which rainfall rapidly infiltrates and there is little or no surface water runoff (Ward and others, 1965). Southern Guam has a dense network of streams because the area is composed primarily of volcanic rocks with limited infiltration capacities. During the Typhoon Chata'an storm, rainfall totals were in excess of $10 \mathrm{in}$. over most of southern Guam, generating significant volumes of surface-water runoff. Peaks flows and/or stages in this area exceeded previous maximums at 14 of the 15 USGS stream gages where flood measurements were made.

During the peak of the storm, it was neither safe nor practical to make direct measurements of peak flows and stages. As a result, a variety of indirect methods based on hydraulic models and hydrologic techniques were used to compute peak stages and flows. The indirect methods used are site specific and had to be tailored to the conditions at each of the USGS stream gages where computations were made (Rantz and others, 1982, chapter 9).

The peak stage recorded at the Ylig River stream gage was $23.45 \mathrm{feet}(\mathrm{ft}), 4.82 \mathrm{ft}$ higher than the previous maximum level recorded since 1953. The peak stage recorded in the Fena Valley Reservoir was $5.36 \mathrm{ft}$ above the spillway crest and $0.86 \mathrm{ft}$ higher than the previous maximum recorded since 1953. The pattern of maximum peak flows closely corresponds to the distribution of rainfall over Guam. For example, the Umatac River was one of the two sites where a new record peak flow was not established during the typhoon. This is also an area where rainfall totals declined sharply from the areas just to the north. USGS stream gages located in the vicinity of the Fena Valley Reservoir had particularly high peak flow rates. USGS stream gages have been operated on the Almagosa and Maulap Rivers since 1972 and on the Ugum River since 1977. The previous peak flows of record for these gages took place in 1978 and 1980 when the Almagosa River peaked at 2,650 cubic feet per second $\left(\mathrm{ft}^{3} / \mathrm{s}\right)$, the Maulap River peaked at 2,420 $\mathrm{ft}^{3} / \mathrm{s}$, and the Ugum River peaked at 5,890 $\mathrm{ft}^{3} / \mathrm{s}$. Peak flow rates during Typhoon Chata'an on the Almagosa, Maulap, and Ugum Rivers of $6,330 \mathrm{ft}^{3} / \mathrm{s}, 5,340 \mathrm{ft}^{3} / \mathrm{s}$, and $14,700 \mathrm{ft}^{3} / \mathrm{s}$ are 239,221 , and 250 percent greater than the previous records.

The distribution of streamflow during Typhoon Chata'an is shown in the plots of hourly discharge included in figure 1 for the Pago River, Maulap River, and La Sa Fua River stream gages. Flow at these selected stream gages responds quickly to periods of high rainfall intensity. At each of the stream gages the sharp increase in flows coincides closely with the onset of the periods of maximum rainfall intensities. The peak flow rates at the three stream gages took place within an hour of the end of the maximum rainfall intensities. Streamflow dropped off sharply from the peaks in conjunction with the rapid reductions in rainfall.

\section{FLOOD FREQUENCY}

The recurrence intervals associated with the flood peaks were computed following the guidelines outlined in Bulletin 17B (Interagency Advisory Committee on Water Data, 1982). Because a generalized map skew has not been computed for Guam, the analyses were based on the station skew at each of the stream gages. At five USGS stream gages, sufficient data to compute recurrence intervals were not available. For those gages the recurrence intervals were estimated using computations summarized in a published flood insurance study for Guam (Federal Emergency Management Agency, 1998). Recurrence intervals were not computed for the Tolaeyuus and Ylig Rivers because peak flow computations for Typhoon Chata' an could not be made at those sites.

The recurrence interval is an estimate of the average number of years between floods of a magnitude that equal or exceed the computed value. For example, a peak flow with a recurrence interval of 100 years is one that would be equaled or exceeded, over the long term, an average of once every 100 years. An alternative way to view the recurrence interval is to take its reciprocal (for example 100 years becomes $1 / 100$ or 0.01 ), which yields the annual exceedance probability. Therefore, a 100-year flood has an annual exceedance probability of 0.01 , or a 1 percent chance of being equaled or exceeded in any given year.

The computed recurrence intervals in years are summarized in table 2 and are shown in figure 1 . With the exception of four stream gages, the computed recurrence intervals were greater than or equal to 80 years. The recurrence intervals at the lower La Sa Fua, Umatac, and Agana River stream gages were 50,15 , and less than 10 years, respectively. These stream gages are located in areas that received less rain than the upland areas of south-central Guam. A recurrence interval of less than 10 years was computed for the Namo River. No rainfall data were available in the immediate area to either support or contradict this apparent outlier. Recurrence intervals were determined to be greater than 100 years for the Asan, Aplacho, and Maulap River and Fena Valley Reservoir gages.

\section{REFERENCES CITED}

Federal Emergency Management Agency, 1998, Flood Insurance Study, Territory of Guam: June 8, 1998 revision, variously paged.

Federal Emergency Management Agency, 2002, Mitigation Operational Strategy, Typhoon Chata'an, FEMA-1426-DR, GU, 9 p.

Interagency Advisory Committee on Water Data, 1982, Guidelines for determining flood flow frequency: Water Resources Council Bulletin 17B, 28 p., 14 app., 1 pl.

Larson, L.W., and Peck, E.L., 1974, Accuracy of precipitation measurements for hydrologic modeling: Water Resources Research, v. 10, no. 4, p. 857-863.

Rantz, S.E., and others, 1982, Measurement and computation of streamflow, volumes 1 and 2: U.S. Geological Survey Water-Supply Paper 2175, 631 p.

For more information contact: U.S. Geological Survey Water Resources 677 Ala Moana Blvd., Suite 415 Honolulu, HI 96813 http://hi.water.usgs.gov/ 


\section{ISLAND OF GUAM}
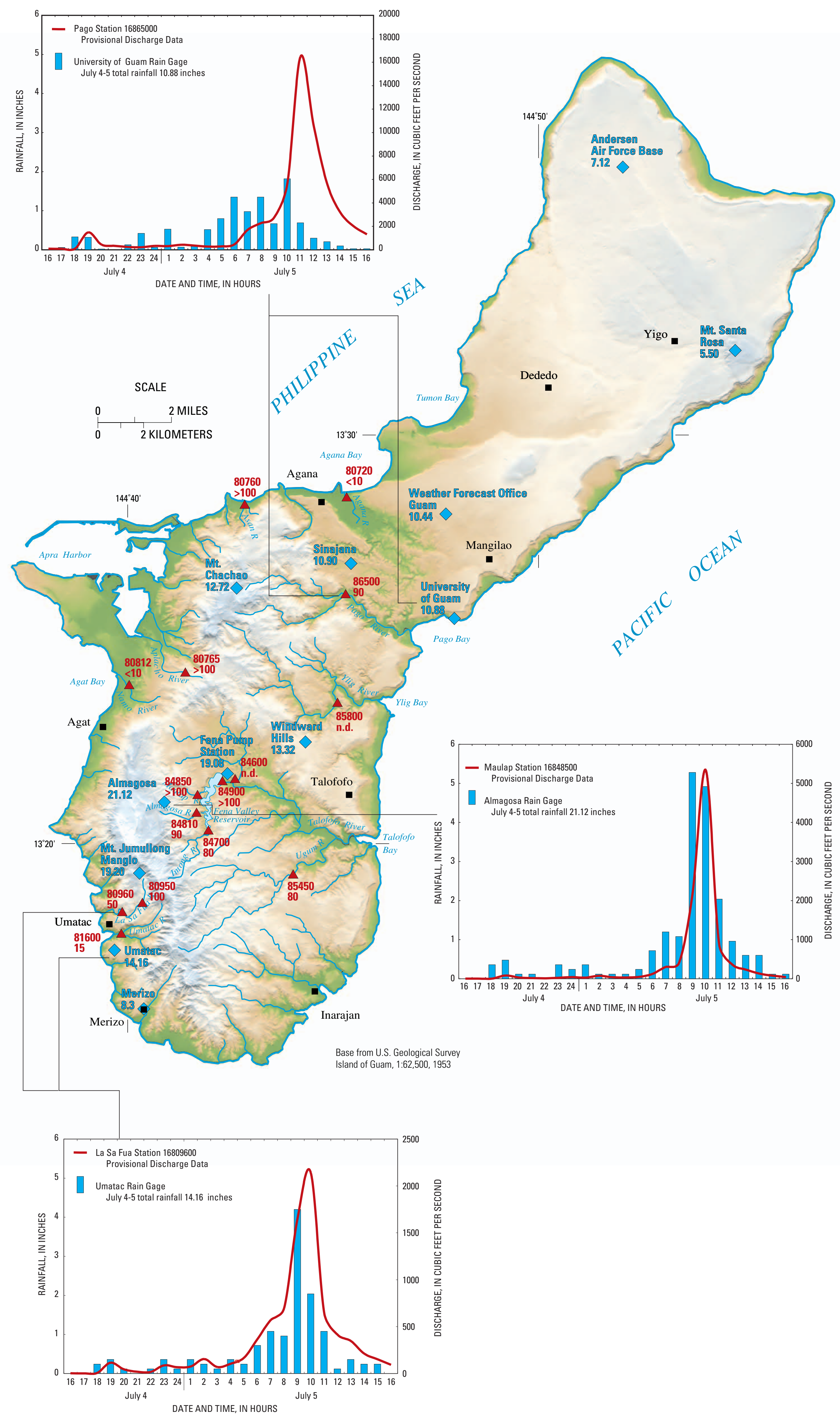

EXPLANATION

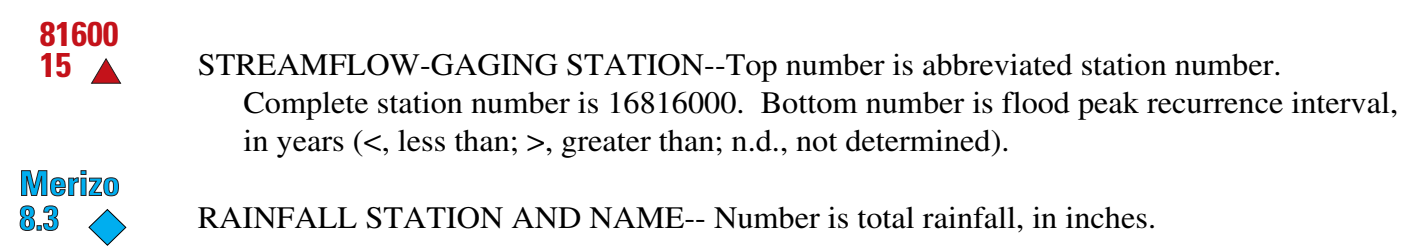

Figure 1. Locations of streamflow-gaging and rainfall stations, storm total rainfall, and flood peak recurrence intervals for Typhoon Chata'an, July 4-5, 2002, Guam. 